УдК 796.51-053.81(510)

\title{
У ЛИНьнА
}

Харьковская государственная академия физической культуры

\section{Роль спортивно-оздоровительного туризма в оздоровлении китайской молодёжи}

\begin{abstract}
Аннотация. Цель: выявить вариативность тактики проведения спортивного тура для развития спортивно-оздоровительного туризма. Материал и методы: анализ и обобщение литературных и электронных источников, официальных шебсайтов. Результаты: выявлены особенности спортивно-оздоровительного туризма и основные потребности подростков Китая в досуге. Отмечено, что появление и развитие ассоциаций спортивно-оздоровительного туризма свидетельствует о массовой популярности среди молодёжи. Выводы: решение проблемы оздоровления китайской молодёжи зависит от развития системного и комплексного подходов к спортивно-оздоровительному туризму.
\end{abstract}

Ключевые слова: молодёжь, спорт, туризм, экскурсия, Китай.

Введение. Значение спортивно-оздоровительного туризма (СОТ), влияющего на оздоровление молодёжи, достаточно велико, поэтому анализ, развитие и эффективное совершенствование данного туризма требует должного научного обоснования. Исследованию видов спортивно-оздоровительного туризма, определяющих результативность оздоровления молодёжи, а также молодёжи Китая, посвящено достаточно много работ [1-12; 14-16], а имеющиеся научные исследования в этой области были направлены в основном на изучение отдельных спортивных туров, в разной мере влияющих на уровень здоровья человека.

Как показывает практика последних лет, спортивно-оздоровительный туризм занимает значительное место в жизни современного общества. С точки зрения его содержания и востребованности выделяется ряд направлений: экономическое, социально-спортивное, культурологическое, социальное, профессионально-педагогическое. Эти направления привлекают внимание отечественных и зарубежных исследователей, что способствует качественно новому уровню изучения проблем спортивно-оздоровительного туризма.

Как отмечается многими исследователями (А. Я. Булашев, О. Ю. Дмитрук, В.А.Квартальнов и др.), отвечающим задачам развития личности является спортивно-оздоровительный туризм, направленный на формирование рационального образа жизни, этических и нравственных ценностей, целостного восприятия окружающего мира, мировоззрения. В научных трудах В.А.Квартальнова, А. Я. Булашева, О. Ю. Дмитрука, Т. И. Гринёвой, Т. Е. Христовой, Ма Цзиньгана, Чжу Фена разработаны методологические основы спортивно-оздоровительного туризма, в комплексе решающего проблемы воспитательного, обучающего, развивающего становления личности.

Цель исследования: цель данного исследования состоит в том, чтобы выявить вариативность тактики проведения спортивного тура для развития спортивно-оздоровительного туризма в стране.

Задачи исследования.

1. На основе анализа литературных источников

dx.doi.org/10.15391/snsv.2014-5.015

(อ) У ЛИНЬНА 2014

$(\mathrm{cc})$ EY рассмотреть особенности спортивно-оздоровительного туризма как неотъемлемой части подготовки спортсмена.

2. Определить роль и исследовать объекты спортивно-оздоровительного туризма для оздоровления молодёжи.

Материал и методы исследования: анализ и обобщение литературных и электронных источников (книги, статьи, авторефераты и тезисы материалов конференций), анализ официальных web-сайтов.

Результаты исследований и их обсуждение. Природные ресурсы Китая способствуют развитию нового вида туристской деятельности в сфере туризма и спорта - спортивно-оздоровительного туризма (СОТ). Недостаточное влияние СОТ на культуру, оздоровление и жизненные процессы китайской молодёжи приводит к развитию рынка СОТ в Китае. Спортивно-оздоровительный туризм адаптируется к потребностям современной китайской молодёжи, которая активно принимает участие в разных мероприятиях [9].

Спортивно-оздоровительный туризм объединил спорт и отдых, что эффективно влияет на физическое и психологическое оздоровление. Содержательным ядром воспитания в спортивно-оздоровительном туризме является совокупность физического и духовно-нравственного воспитания. Здесь происходит физическое совершенствование человека с одновременным совершенствованием его нравственной сферы: сознания, поведения, чувств, отношений. Также СОт объединил наиболее эффективные оздоровительные виды рекреационной деятельности для детей и людей пожилого возраста [12].

За последние 25 лет спортивно-оздоровительный туризм сформировался в крупных городах Китая, таких как Пекин, Шанхай, Гуанчжоу и другие. Средства массовой информации популяризируют тему СОТ среди молодёжи и старшего поколения на территории всего Китая. Например, в Пекинском университете уже 25 лет существует ассоциация СОТ «Шань Ин»[14].

Кроме этого, существует китайская ассоциация альпинизма, которая организует различные соревнования по некоторым видам туризма: походы, альпинизм, скалолазание, экстремальные виды спорта, лыжный спорт. Большинство ассоциаций СОТ созда- 
вались студентами: ассоциация «Шушан» (г. Чэнду), ассоциация Сямэньского университета, ассоциация «Шань Но» (г. Пекин), сообщество «Чи Цзи» (г. Синьцзянь), ассоциация «Люй Е» (г. Сямэнь), ассоциация «Хун Ин» (г. Пекин). Появление ассоциаций и сообществ в городах Китая способствовало развитию других видов спортивно-оздоровительного туризма: велосипедный спорт, гребля на каноэ, охрана и защита окружающей среды, парапланеризм, «выживание в глуши» и т. д.

Появление и развитие ассоциаций СОТ свидетельствует о массовой популярности спортивно-оздоровительного туризма среди населения Китая, привлечении большого капитала, постоянном приросте занимающихся. По всей стране создаются благоприятные условия для развития спортивно-оздоровительного туризма для населения Китая.

К сожалению, трагические случаи, которые происходили с туристами, занимающимися экстремальными видами спорта (альпинизм, скалолазание и др.), влияли на популярность спортивно-оздоровительного туризма, что постоянно приводило к возобновлению и поиску новых способов безопасного спортивного туризма. Отсутствие научно-производственной базы, проверенных безопасных маршрутов, опытных инструкторов, специализированной литературы, необходимого снаряжения, подготовленных кадров и обслуживающего персонала создаёт проблемы для спортивно-оздоровительного туризма и влияет на его популярность. Поэтому для развития СОТ в Китае необходимо решение перечисленных проблем.

Как показали последние исследования в области спортивно-оздоровительного туризма, необходимо проводить сравнительный анализ кадров разных стран, выполнять обмен полезным опытом, совершенствовать подготовку кадров в Китае, проводить постоянные опытные проверки текущих кадров, поддерживать инициативных тренеров СОТ, развивать молодые кадры.

Исходя из проведённого анализа досуга молодёжи, организация подросткового туризма в образовательном учреждении через научно-исследовательскую деятельность имеет большое значение в раскрытии творческих способностей личности подростков, а главное способствует активизации их познавательной деятельности, оздоровлению.

Современные тенденции в развитии подросткового отдыха и туризма свидетельствуют о возрастающем его влиянии. Становится очевидным превращение подросткового туризма и активного летнего отдыха в крупную самостоятельную отрасль, деятельность которой направлена на удовлетворение специфических потребностей школьников. Многообразие этих потребностей удовлетворяется не только туристическими предприятиями, но и самими общеобразовательными учреждениями. Более того, подростковый туризм входит в число основных потребностей учащегося, в значительной степени способствует снятию эмоциональных и психических нагрузок, оздоровлению, а также включению подростков в исследовательскую деятельность.

Подготовка спортсменов-туристов - многолетний учебно-воспитательный процесс, в котором собственно тренировочный период (обеспечение общей и специальной физической, технической, тактической и психологической подготовленности участников спортивных туристских походов и соревнований) является составной частью. Другая его часть - обучение, включающее теоретическую, организационно-методическую и специальную подготовку (естественно-географическую, краеведческую, педагогическую), а также вопросы методики организации, подготовки и проведения туристских мероприятий, судейства, гигиены, доврачебной помощи и т. п. [1;7].

Многолетняя подготовка (обучение по программе туристских общественных кадров и спортивная тренировка) распадается на годичные циклы и строится на основе перспективного планирования, а годичный цикл - на основе оперативного планирования [8].

В круглогодичном цикле выделяются три периода - подготовительный, основной и переходный. Наиболее продолжительный - первый период (более 10 месяцев) имеет целью всестороннюю подготовку участников туристских мероприятий (спортивного похода, соревнований); сравнительно короткий (до одного месяца - время отпуска или студенческих каникул), второй период - участие в спортивном походе (соревнованиях). Еще более короткий (одна-две недели) третий период включает прохождение участниками туристских мероприятий, медицинского и педагогического послепоходного контроля, активный отдых и подведение итогов похода (соревнований) разбор и анализ, подготовку отчета, определение цели и задач на следующий годичный цикл, комплектование группы (команды) для подготовки к участию в спортивных мероприятиях следующего основного периода, составление плана подготовки.

Китай располагает огромной территорией с разнообразным ландшафтом, обладая уникальными памятниками природы и архитектурными шедеврами, созданными китайским народом на протяжении нескольких тысячелетий. Концепция развития физической культуры, спорта и туризма в стране за последние 10 лет привлекло около 40\% населения для занятия спортом и туризмом, что способствует укреплению здоровья граждан Китая. Внедрение и массовое развитие спортивно-оздоровительного туризма в Китае позволило получить положительные результаты: снизилась общая заболеваемость, повысилась производительность труда, возросла продолжительность жизни, повысился культурный уровень населения, частично решилась проблема здорового образа жизни и отдыха населения. Средства массовой информации получили интересные, уникальные материалы о Китае от путешествующих, что привлекло через туризм к здоровому образу жизни также и иностранных туристов. При этом последние результативные достижения в большом спорте также способствовали привлечению китайской молодёжи к спорту и туризму.

Китай - это прежде всего громадный пласт истории, памяти, времени, и всего, что должно быть дорого всему человечеству для понимания своего значения в этом мире вообще и сохранения памяти и развития цивилизации людей в целом. Это уникальный исторический казус слияния одного во многом и совершенно казалось бы несовместимом, место концентрации всего и вся, кладезь памятников и сокровищ, место контакта прошлого и будущего и взаимный проникновенный симбиоз, древнейшая цивилизация и одновременно коммунистический рай. На 
Экскурсионные объекты Китая по версии ЮНЕСКО

\begin{tabular}{|c|c|c|c|}
\hline № $\mathbf{n} / \mathbf{n}$ & Название & Местонахождение & Год \\
\hline 1. & Императорские дворцы династий Мин и Цин (Запретный Город) & г. Пекин & 1987 \\
\hline 2. & Стоянка «пекинского человека» в Чжоукоудяне & г. Пекин & 1987 \\
\hline 3. & Великая Китайская Стена (застава Шаньхайгуань) & & 1987 \\
\hline 4. & Мавзолей первого императора династии Цинь, терракотовая армия & пр. Шанькси & 1987 \\
\hline 5. & Гора Тайшань & г. Тайшань & 1987 \\
\hline 6. & Заповедник гора Хуаншань & пр. Аньхой & 1990 \\
\hline 7. & Пейзажный и исторический район Улинъюань & пр. Хунань & 1992 \\
\hline 8. & Национальный парк Цзючжайгоу & пр. Сычуань & 1992 \\
\hline 9. & Заповедник Хуанлун & пр. Сычуань & 1992 \\
\hline 10. & Горная резиденция, летний дворец династии Цин & г. Чэндэ & 1994 \\
\hline 11. & Древние сооружения в горах Уданшань & пр. Хубэй & 1994 \\
\hline 12. & Храм и гробница Конфуция и имение семьи Кун & г. Цюйфу & 1994 \\
\hline 13. & Национальный парк Лушань & пр. Цзянси & 1996 \\
\hline 14. & Гигантская статуя Будды и Гора Эмэй & пр. Сычуань & 1996 \\
\hline 15. & Древний город Пинъяо & пр. Шанькси & 1997 \\
\hline 16. & Старый город Лицзян & пр. Юньнань & 1997 \\
\hline 17. & Классические китайские сады в городе Сучжоу & пр. Цзянсу & 1997 \\
\hline 18. & $\begin{array}{l}\text { Летний дворец и императорский парк. Парк Ихэюань в Пекине (Летний } \\
\text { императорский дворец) }\end{array}$ & г. Пекин & 1998 \\
\hline 19. & Храм Неба & г. Пекин & 1998 \\
\hline 20. & Горы Уишань & пр. Фуцзянь & 1999 \\
\hline 21. & Пещеры Дацзу & округ Дацзу & 1999 \\
\hline 22. & Гробницы императоров династий Мин и Цин & г. Пекин & 2000 \\
\hline 23. & Старинные деревни на юге провинции & пр. Аньхой & 2000 \\
\hline 24. & Пещеры Лунмэнь & г. Лоян & 2000 \\
\hline 25. & Горы Цинчэн (Цинчэншань) и Ирригационный проект Дуцзянъянь & пр. Сычуань & 2000 \\
\hline 26. & Пещерные храмы Юньган & г. Дотонг & 2001 \\
\hline 27. & Национальный парк «Три параллельные реки» & пр. Юньнань & 2003 \\
\hline 28. & Столичные города и гробницы древнего царства Когурё & пр. Цзиань & 2004 \\
\hline 29. & Исторический центр города Макао (Аомэнь) & пр.Макао & 2005 \\
\hline 30. & Иньсюй - столица древнего государства Шан & пр. Хенань & 2006 \\
\hline 31. & Центр разведения и исследования большой панды в Чэнду & пр. Сычуань & 2006 \\
\hline 32. & Гуанчжоу. Дяолоу и деревни Кайпина & пр. Гуандун & 2007 \\
\hline 33. & Южно-Китайский карст & пр. Юньнань & 2007 \\
\hline 34. & Национальный парк горы Саньциншань & пр. Цзянси & 2008 \\
\hline 35. & Глинобитные дома Тулоу & пр. Фуцзянь & 2008 \\
\hline 36. & Гора Утайшань & г. Утайшань & 2009 \\
\hline 37. & Исторические памятники Денфен в «Центре Неба и Земли» & пр. Хенань & 2010 \\
\hline 38. & Цветные скалы Данься & & 2010 \\
\hline 39. & Озеро города Ханчжоу & г. Ханчжоу & 2011 \\
\hline 40. & Археологические раскопки на территории города Шанду & пр. Шанду & 2012 \\
\hline 41. & Палеонтологический заповедник Чэнцзян & пр. Юньнань & 2012 \\
\hline 42. & Рисовые террасы в Honghe Hani & пр. Юньнань & 2013 \\
\hline
\end{tabular}


его огромной территории от курортного Хайнаня до мертвых песков пустыни Гоби, от задевающих облака небоскребов Шанхая до ледников Тибета разбросаны уникальные места, внесенные в список наследия Юнеско [13], всего на данный момент 42 (табл.).

Перечисленные экскурсионные объекты не требуют значительной физической нагрузки от туристов, но в то же время они входят в программу оздоровительных и спортивных походов как составная часть планируемого маршрута. Спортивно-оздоровительный туризм заключается в том, что при разработке маршрута заранее планируется посещение не только природных памятников, но и экскурсионных объектов и достопримечательностей, расположенных на территории, избранной для выбранного похода.

Выводы. Изучение и анализ литературы позволили выявить особенности спортивно-оздоровительного туризма и основные потребности подростков Китая в общении, развлечениях, активном и подвижном отдыхе. Все эти потребности можно реализовать для спортсменов-подростков в туризме и летнем отдыхе. Отличительной особенностью подросткового и молодежного туризма является то, что подростки являются самой непритязательной социально-демографической группой. Для молодёжи необязательны высококлассные условия в туристической поездке, ее в большей степени интересует определенный уровень комфорта, умеренные цены и насыщенная культурнодосуговая деятельность, отвечающая их возрастным потребностям. Реализация имеющегося потенциала возможна только при условии системного и комплек- сного подхода к решению проблем, сдерживающих развитие туризма.

Проведено исследование объектов спортивнооздоровительного туризма с целью оздоровления молодёжи. В процессе достижения поставленной цели была изучена и проанализирована специальная литература, что позволило рассмотреть структуру подросткового и молодежного туризма, раскрыть его особенности, а также определить роль ассоциаций спортивно-оздоровительного туризма. Было выявлено 42 экскурсионных объекта на всей территории Китая по версии ЮНЕСКО, что позволит проводить досуг подростков и молодежи в силу специфических потребностей и присущих ей социально-психологических особенностей «молодежного сознания», повышенной эмоциональностью восприятия и реакций. В основе его содержания не только отдых и развлечения, но и решения жизненных проблем, т. к. идет активный процесс самопознания, самореализации, самовыражения. Ценностные ориентации на культурно-досуговую деятельность зависят от возможности удовлетворения личных потребностей китайской молодёжи, опираясь на различные подходы.

Перспективы дальнейших исследований. Определение роли спортивно-оздоровительного туризма, влияющего на оздоровление китайской молодёжи, позволит изменить подготовку туристов в юношеском возрасте, а также увеличить результативность во время туров и соревнований. Дальнейшие исследования позволят расставить приоритеты наибольшего влияния на результативность.

\section{Список использованной литературы:}

1. Булашев А. Я. Спортивный туризм: учебник / А.Я. Булашев. - Харьков, 2009. - 331 c.

2. Ван Сюемань. Направления развития физической культуры в КНР / Ван Сюемань // Слобожанський науково-спортивний вісник. - Харків : ХДАФК, 2013. - № 2. - С. 172-176.

3. Ван Цзин. Организация физического воспитания детей и молодежи в Китайской народной республике / Ван Цзин, А.С. Бондарь // Слобожанський науково-спортивний вісник. - Харків : ХДАФК, 2013. - № 5. - С. 45-48.

4. Гриньова Т. І. Визначення рівня фізичного здоров'я дітей 10-13 років, що займаються туризмом за авторською програмою «Туристське багатоборство» / Т. І. Гриньова, К. В. Мулик //Слобожанський науково-спортивний вісник. - Харків : ХДАФК, 2014. - № 1. - С. 22-27.

5. Гриньова Т. І. Мотиви та зацікавленість дітей до занять різними видами спортивного туризму / Т. І. Гриньова //Слобожанський науково-спортивний вісник. - Харків : ХДАФК, 2013. - № 5. - С. 82-85.

6. Денисенко И. А. Эффективность использования средств спортивно-оздоровительного туризма в повышении физической подготовленности девушек 18-19 лет / И. А. Денисенко // Слобожанський науково-спортивний вісник. - Харків : ХДАФК, 2013. - № 3. - С. 24-28.

7. Дмитрук О. Ю. Спортивно-оздоровчий туризм: навч. посібник / О. Ю.Дмитрук, Ю. В. Щур. - К. : Альтерпрес, 2008. $-280 c$.

8. Квартальнов В. А. Туризм / В. А. Квартальнов. - М.: Финансы и статистика, 2002. - 320 с.

9. Ма Цзиньган. Туристские ресурсы Китая: их роль и значение для развития спортивно-оздоровительного туризма в стране / Ма Цзиньган // Физическое воспитание студентов творческих специальностей : [сб. научных трудов под ред. Ермакова С. С.] - Харьков : ХГАДИ (ХХПИ), 2003. - № 7. - С. 74-80.

10. Сутула В. А. Предпосылки формирования в обществе потребности в здоровом образе жизни / В. А. Сутула // Физическое воспитание студентов : [научный журнал]. - Харьков : ХООНОКУ-ХГАДИ, 2011. - № 6. - С. 92-95.

11. Христовая T. Е. Современное состояние здоровья студентов и пути его совершенствования / Т. Е. Христовая // Слобожанський науково-спортивний вісник. - Харків : ХДАФК, 2013. - № 1. - С. 74-78.

12. Чжу Фен. Истографический подход в исследовании средств и форм физической культуры и спорта в Китае / Чжу Фен, Ван Лихуа // Слобожанський науково-спортивних вісник : [наук.-теорет. журн.]. - Харків : ХДАФК, 2008. - № 4. - С. 235-238.

13. UNESCO: World Heritage Centre [Электронный ресурс]/UNESCO. - Режим доступа : http://whc.unesco.org.

14. 张超. 不同年龄段青少年篮球运动员弱侧手能力训练的实验研究. 东北师范大学, 2010. -217页.

15. 王晓春. 试论青少年篮球运动员赛前心理调节与控制. 品牌 (理论月刊), 2010. - 12. - 197页.

16. 吕静, 丁土良. 浅谈青少年篮球训练应注意的几个问题. 少年体 育训练, 2010. - 4. - 204页.

Стаття надійшла до редакції: 19.09.2014 p. Опубліковано: 31.10 .2014 p.

Анотація. У Ліньна. Роль спортивно-оздоровчого туризму для оздоровлення китайської молоді. Мета: виявити варіативність тактики проведення спортивного туру для розвитку спортивно-оздоровчого туризму. Матеріал і методи: аналіз і узагальнення літературних і електронних джерел, офіційних web-сайтів. Результати: виявлено особливості спортивно-оздоровчого туризму та основних потреб підлітків Китаю в дозвіллі. Зазначено, що поява і розвиток асоціацій спортивно-оздоровчого туризму свідчить про масову популярність серед молоді. Висновки: вирішення проблеми оздоровлення 
китайської молоді залежить від розвитку системного і комплексного підходу до спортивно-оздоровчого туризму.

Ключові слова: молодь, спорт, туризм, екскурсія, Китай.

Abstract. Wu Linna. The role of sport tourism for the recovery of the Chinese youth. Purpose: to identify the variability tactics of the sport tour for the development of sport tourism. Material and Methods: analysis and generalization of literature and electronic sources, official web-sites. Results: the identified peculiarities of sport tourism and the basic needs of adolescents in China leisure. It is noted that the emergence and development of associations of sport tourism indicates mass popularity among young people. Conclusions: addressing health of Chinese youth depends on the development of systematic and comprehensive approaches to sports and health tourism.

Key words: youth, sport, tourism, tour, China.

\section{References:}

1. Bulashev A. Ya. Sportivniy turizm: uchebnik, 2009, 331 p. (rus) 176. (rus)

2. Van Xuemang. Slobozans'kij nauk. -sport. visn. [Slobozhanskyi science and sport bulletin], Kharkiv, 2013, vol. 2, pp. 172-

3. Wang Jing. Slobozans'kij nauk. -sport. visn. [Slobozhanskyi science and sport bulletin], Kharkiv, 2013, vol. 5, pp. 45-48. (rus) (rus)

4. Grynova T.I. Slobozans'kij nauk. -sport. visn. [Slobozhanskyi science and sport bulletin], Kharkiv, 2014, vol. 1, pp. 22-27. (rus)

5. Grynova T.I. Slobozans'kij nauk. -sport. visn. [Slobozhanskyi science and sport bulletin], Kharkiv, 2013, vol. 5, pp. 82-85.

6. Denisenko I.A. Slobozans'kij nauk. -sport. visn. [Slobozhanskyi science and sport bulletin], Kharkiv, 2013, vol. 3, pp. 2428. (rus)

7. Dmytruk O. Yu. Sportivno-ozdorovchiy turizm: navch. posibnyk, 2008, 280 p. (ukr)

8. Kvartalnov V. A. Turizm, 2002, 320 p. (rus)

9. Ma Tszingan. Fizicheskoye vospitaniye studentov tvorcheskikh spetsialnostey [Physical education students of creative disciplines], Kharkov, 2003, vol. 7, pp. 74-80. (rus)

10. Sutula V. A. Fizicheskoye vospitaniye studentov [Physical education students], Kharkov, 2011, vol. 6, pp. 92-95. (rus)

11. Khristovaya T. Ye. Slobozans'kij nauk.-sport. visn. [Slobozhanskyi science and sport bulletin], Kharkiv, 2013, vol. 1, pp. 74-78. (rus) (rus)

12. Zhu Fen. Slobozans'kij nauk. -sport. visn. [Slobozhanskyi science and sport bulletin], Kharkiv, 2008, vol. 4, pp. $235-238$.

13. UNESCO: World Heritage Centre, Access mode : http://whc. unesco.org

14. 张超. 不同年龄段青少年篮球运动员弱侧手能力训练的实验研究. 东北师范大学, 2010. -217 页.

15. 王晓春. 试论青少年篮球运动员赛前心理调节与控制. 品牌 (理论 月刊), 2010. - 12. - 197页.

16. 吕静, 丁士良. 浅谈青少年篮球训练应注意的几个问题. 少年体 育训练, 2010. - 4. - 204页.

Received: 19.09 .2014 Published: 31.10 .2014

У Ліньна: Харківська державна академія фізичної культури: вул. Клочківська 99, Харків, 61058, Україна.

у Линьна: Харьковская государственная академия физической культуры: ул. Клочковская 99, г.Харьков, 61058, Украина.

Wu Linna: Kharkiv State Academy of Physical Culture: Klochkovskaya str. 99, Kharkiv, 61058, Ukraine.

E-mail: vitalij.brusentsev@ukr.net 